\title{
Characterization of digestive enzymes from captive Brazilian flounder Paralichthys orbignyanus
}

\author{
F. B. Candiotto ${ }^{a *}$, A. C. V. Freitas-Júnior ${ }^{b}$, R. C. A. Neric, R. S. Bezerra ${ }^{c}$, R. V. Rodrigues ${ }^{\text {, }}$ \\ L. A. Sampaio and M. B. Tesser ${ }^{a}$ \\ áLaboratório de Nutrição de Organismos Aquáticos, Programa de Pós-graduação em Aquicultura, Instituto de \\ Oceanografia, Universidade Federal do Rio Grande - FURG, Av. Cassino, 200, Lot Querência, Bairro Cassino, \\ CEP 96210-000, Rio Grande, RS, Brazil
}

\begin{abstract}
bDepartamento de Biologia Molecular, Centro de Ciências Exatas e da Natureza - CCEN, Universidade Federal da Paraíba - UFPB, Cidade Universitária, s/n, Castelo Branco, CEP 58051-900, João Pessoa, PB, Brazil

'Laboratório de Enzimologia - LABENZ, Programa de Pós-graduação em Bioquímica e Fisiologia Departamento de Bioquímica - CCB, Universidade Federal de Pernambuco - UFPE, Av. Prof. Moraes Rego, 1235, Cidade Universitária, CEP 50670-901, Recife, PE, Brazil

${ }^{d}$ Laboratório de Piscicultura Estuarina e Marinha, Programa de Pós-graduação em Aquicultura, Instituto de Oceanografia, Universidade Federal do Rio Grande - FURG, Av. Cassino, 200, Lot Querência, Bairro Cassino, CEP 96210-000, Rio Grande, RS, Brazil

*e-mail: fernandabcandiotto@gmail.com
\end{abstract}

Received: May 6, 2016 - Accepted: December 30, 2016 - Distributed: May 31, 2018

(With 2 figures)

\begin{abstract}
Knowledge of specific enzyme activity, along with animal habits and digestive capacity is essential in formulating an appropriate diet for any species. In this study, we evaluated and characterized the activity of digestive enzymes present in the liver, intestine, and stomach of Paralichthys orbignyanus. The effects of $\mathrm{pH}$ and temperature on enzyme activity were also evaluated via the use of specific substrates. The use of specific substrates and inhibitors showed strong evidence of the presence of trypsin $\left(\mathrm{BA} p \mathrm{NA}=0.51 \pm 0.2 \mathrm{mU} \mathrm{mg}^{-1}\right)$, chimotrypsin $\left(\mathrm{SA} p \mathrm{NA}=2.62 \pm 1.8 \mathrm{mU} \mathrm{mg}^{-1}\right)$, and aminopeptidases (Leu- $p$-Nan $=0.9709 \pm 0.83 \mathrm{mU} \mathrm{mg}^{-1}$ ) in the intestine. Optimum $\mathrm{pH}$ for the activity of trypsin, chemotrypsin, leucino aminopeptidase, amilase, and pepsin were 9.5, 9.0, 8.0, 7.5, and 3.5, respectively, while optimum temperatures were $50,50,50,40$, and $45^{\circ} \mathrm{C}$, respectively. These results provide additional information regarding the biology of Brazilian flounder and can be used as a basis for further studies regarding fish feeding physiology.
\end{abstract}

Keywords: trypsin, protease, digestive tract.

\section{Caracterização de enzimas digestivas do linguado brasileiro de cativeiro Paralichthys orbignyanus}

\section{Resumo}

O conhecimento da atividade enzimática é essencial para formular uma correta dieta específica para espécie, além de estarem correlacionadas com o hábito da alimentação e capacidade digestive. Neste estudo determinamos e caracterizamos a atividade enzimática presente no intestino, estômago e fígado do linguado Paralichthys orbignyanus. Os efeitos da temperatura e $\mathrm{pH}$ sobre a atividade enzimática também foram avaliados utilizando substratos específicos. $\mathrm{O}$ uso de substratos e inibidores específicos mostrou uma forte evidência da presença da tripsina (BApNA $=0,51 \pm 0,2 \mathrm{mU} \mathrm{mg}-1$ ), quimotripsina (SAPNA $=2,62 \pm 1,8 \mathrm{mU} \mathrm{mg}-1$ ), e as aminopeptidases (Leu-p-Nan $=0,97 \pm 0,83 \mathrm{mU}$ mg-1) no intestino. $\mathrm{O}$ pH ótimo observado para a atividade de tripsina, quimotripsina, leucino aminopeptidase, amilase e pepsina foi 9,5, $9,0,8,0,7,5$ e 3,5 , respectivamente. A temperatura ótima observada foi 50, 50, 50, 40 e $45^{\circ} \mathrm{C}$, respectivamente. Estes resultados fornecem informações adicionais sobre a biologia do linguado brasileiro e pode ser usado como base para novos estudos sobre fisiologia alimentar.

Palavras-chave: tripsina, proteases, trato digestório. 


\section{Introduction}

The Brazilian flounder, Paralichthys orbignyanus (Valenciennes, 1842) is a native species that inhabits coastal and estuarine areas from Rio de Janeiro - Brazil, to Mar del Plata-Argentina; however, is found in greater abundance in southern Brazil (Bianchini et al., 2010). The flounder fishery industry in the southern region of Brazil has been considered an important resource, however in the last few years has stagnated in capture rates (Brasil, 2010). Thus, aquaculture for this species may be considered as an alternative resource to increase market supply (Sampaio et al., 2008). Reproduction and larviculture of Brazilian flounder is well established (Bianchini et al., 2010), and the effects of salinity on growth are also known (Sampaio et al., 2007); these represent important features to be considered in a new species for coastal and estuarine aquaculture. However, there is a lack of current literature related to the digestive physiology and nutritional requirements of this species.

Feeding is one of the most expensive factors in aquaculture, often representing more than $50 \%$ of total costs (Alam et al., 2009). In this sense, it is important to offer well balanced diets that promote maximum fish growth while reducing production costs and nitrogenous residues to the environment (Gatlin, 2010). Relevant information regarding enzymatic activity and the digestive processes from each fish species is essential for developing correct feeding formulations (López-López et al., 2005). Therein, digestive enzyme patterns are correlated to fish feeding habits and digestive capacity (Kuz'mina et al., 2011).

In this study, the activites of digestive enzymes present in the intestine, stomach and liver of Brazilian flounder were characterized.

Trypsin, chymotrypsin, pepsin and aminopeptidase are among the most important digestive enzymes in Brazilian flounder, due to their high proteolytic activities (Parra et al., 2007). Trypsin is considered a key proteolityc and self-activated enzyme, which may also influence the activity of other pancreatic zymogens, and potentially limit growth rate in the cod Gadus morhua (Lemieux et al., 1999). Amylase is the primary glucosidase found in fish. Amylase hydrolyses $\alpha 1-4$ bonds present in amylose, glycogen, or linear fragments of amylopectin secreted by pancreatic cells (Krogdahl et al., 2005). Amylase activity has been observed in several teleosts (including herbivorous to strictly carnivourous fish) at different portions of the digestive tract, although mainly in the pyloric cecum, liver and pancreas (Deng et al., 2010).

Thus, the aim of this study was to identify and partially characterize digestive enzymes present in the liver, stomach and intestine of Brazilian flounder, thereby providing relevant information regarding the biology and digestive physiology of the species.

\section{Material and Methods}

\subsection{Experimental fish}

A total of 41 unsexed juvenile Brazilian flounders (mean weight $112 \pm 35 \mathrm{~g}, 4$ months of age) were used in this study. Fish were reared at the Laboratório de Piscicultura
Estuarina e Marinha - FURG, according to the protocol of Sampaio et al. (2008). Fish were euthanized with high benzocaine concentration (500 ppm) and complete digestive tracts were immediately dissected on ice. Stomach, liver and intestine were deep-frozen and all enzymatic assays were conducted at the Laboratório de Enzimologia - UFPE. All assay reagents were obtained from Sigma (St. Louis, MO, USA) and Merck (Darmstadt, Germany).

\subsection{Crude extract preparation and determination of total soluble protein}

The digestive tracts of 41 juveniles were subdivided into three groups $(14,14$ and 13) in case of loss of material. Collected organs $(1 \mathrm{~g} / \mathrm{mL})$ were homogenized in chilled $0.15 \mathrm{M}$ $\mathrm{NaCl}$ using a tissue homogenizer (IKA RW 20 digital) at $615 \mathrm{rpm}$ for 10 minutes. Crude extracts were obtained from supernatants following centrifugation $(10,000 \times g, 25 \mathrm{~min}$, $4{ }^{\circ} \mathrm{C}$ ) and lipid removal, and then stored at $-20^{\circ} \mathrm{C}$ for later use. Total soluble protein contents of crude extracts were determined using bovine serum albumin as the standard protein (Bradford, 1976).

\subsection{Non-specific enzyme assays}

Total protease alkaline activity was assayed through hydrolysis of $1 \%$ azocasein dissolved in $0.1 \mathrm{M}$ Tris- $\mathrm{HCl}$ buffer $\mathrm{pH}$ 8.0. Triplicate samples $(30 \mu \mathrm{L})$ of crude intestine extract were incubated with substrate solution $(50 \mu \mathrm{L})$ for $60 \mathrm{~min}$ at $25^{\circ} \mathrm{C}$ in a microtube (Bezerra et al., 2005). The reaction was stopped with the addition of $10 \%$ trichloroacetic acid $(240 \mu \mathrm{L})$ and the mixture was centrifuged at $8,000 \times g$ for 5 min. Unhydrolysed substrate was sedimented and the supernatant was recovered and then further mixed $(70 \mu \mathrm{L})$ with $1 \mathrm{M} \mathrm{NaOH}(130 \mu \mathrm{L})$. The absorbance of supernatants was measured in a microtitre plate reader (Bio-Rad 680, Japan) at $450 \mathrm{~nm}$. Changes in absorbance over time were calculated by the differences between reactions stopped at zero (blank controls) and after $10 \mathrm{~min}$.

Total acid proteolytic activity was determined (triplicate) according to the methodology described by Khaled et al. (2011), with modifications to substrate concentration, incubation time, temperature and $\mathrm{pH}$ of the buffer. A mixture $(100 \mathrm{~mL})$ containing $2 \%$ hemoglobin (w/v) pH 2.5, $50 \mu \mathrm{L}$ of crude stomach extract, and $350 \mu \mathrm{L}$ of glycine $-\mathrm{HCl} 0.1 \mathrm{M}$ buffer $\mathrm{pH} 2.5$ was incubated for $30 \mathrm{~min}$ at $37^{\circ} \mathrm{C} .500 \mu \mathrm{L}$ of $10 \%$ trichloroacetic acid (w/v) was added after 30 minutes and the mixture was incubated for a further $15 \mathrm{~min}$ at $25^{\circ} \mathrm{C}$. The mixture was centrifuged at $10,000 \times g$ for $10 \mathrm{~min}$ and the absorbance of the supernatant was analyzed at $280 \mathrm{~nm}$. A control reaction was performed by replacing the crude stomach extract with $0.15 \mathrm{M} \mathrm{NaCl}$. In addition, another control was performed by replacing the $2 \%$ hemoglobin with glycine- $\mathrm{HCl} 0.1 \mathrm{M} \mathrm{pH} 2.5$ buffer.

One unit of total protease activity (U) was expressed as the amount of enzyme required to hydrolyse azocasein or hemoglobin and produce a 0.001 change in absorbance per millilitre per minute. Specific protease activity was expressed in units per milligram of protein. All values were presented as means \pm standard deviations. 


\subsection{Specific enzyme assays}

Activites of trypsin, chymotrypsin, and leucine aminopeptidase were determined in microplates according to Buarque et al. (2010) using their specific substrates: BapNA (N $\alpha$-benzoyl-DL-arginine-p-nitroanilide), $8 \mathrm{mM}$ Sapna (succinyl - alanine phenylalanine proline alanine - $\mathrm{p}$ nitroanilide), and $4 \mathrm{mM}$ p-Nan-Leu (leucine-p nitroanilide) $8 \mathrm{mM}$. DMSO (dimethyl sulfoxide) was used as the solvent for all substrates. All assays were performed in triplicate. Crude intestine extract $(30 \mu \mathrm{L})$ was incubated with $140 \mu \mathrm{L}$

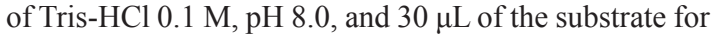
a period of $15 \mathrm{~min}$ at $25^{\circ} \mathrm{C}$. Absorbance readings were measured and recorded using a microplate reader (Bio-Rad Model X-Mark TM, USA) at $405 \mathrm{~nm}$ wavelength. One unit of activity $(U)$ was defined as the amount of enzyme required to produce $1 \mu \mathrm{mol}$ of $\mathrm{p}$-nitroanilide per minute. The specific activity was expressed as units per milligram of protein. All values were presented as means \pm standard deviations.

\subsection{Amylolytic activity}

Total amylase activity was based on the method of Bernfeld (1955) using starch solution at 2\%(w/v) as substrate. The reaction consisted of incubating $20 \mu \mathrm{L}$ of the crude liver extract and intestine (crude liver or intestine extract) with $125 \mu \mathrm{L}$ of $0.1 \mathrm{M}$ Tris- $\mathrm{HCl}, \mathrm{pH} 8$, and $125 \mu \mathrm{L}$ of substrate at $37^{\circ} \mathrm{C}$ for 10 minutes. Then, $30 \mu \mathrm{L}$ of solution was incubated with DNSA (acid 3.5 dinitrosalicylic) at $100{ }^{\circ} \mathrm{C}$ for 10 minutes. Immediately after cooling, $200 \mu \mathrm{L}$ of the solution was transferred to a microplate and the absorbance was measured at $570 \mathrm{~nm}$ using a microplate reader (Bio-Rad Model X-Mark ${ }^{\mathrm{TM}}$, USA). One unit of enzyme activity was expressed in $\mu \mathrm{g}$ of maltose liberated at $37^{\circ} \mathrm{C}$ per minute per mg protein. A calibration curve using commercial maltose was used to determine the concentration of liberated maltose. All values were presented as means \pm standard deviations.

\subsection{Effects of $\mathrm{pH}$ and temperature on enzyme activity}

The effects of $\mathrm{pH}$ and temperature on amylolytic and proteolytic activity from crude extract of intestine, stomach and liver of Brazilian flounder were evaluated using Tris- $\mathrm{HCl}$, citrate-phosphate and glycine- $\mathrm{NaOH}$ buffers (at a final concentration of $0.1 \mathrm{M}, \mathrm{pH}$ ranging from 4.5 to 11.5 for alkaline activity and 1.5 to 6.5 for acid activity and temperature of $25-70{ }^{\circ} \mathrm{C}$ for both $\mathrm{pH}$ ranges). Thermal stability was evaluated by analyses of enzymatic activity at $25^{\circ} \mathrm{C}$ after pre-incubation for 30 minutes at temperatures ranging from $25-70{ }^{\circ} \mathrm{C}$ (Bezerra et al., 2005). All values were presented as means \pm standard deviations.

\subsection{Inhibitiors assays}

Inhibitors were prepared in DMSO at concentrations of $8 \mathrm{mM}$ : phenylmethylsulfonyl fluoride (PMSF - serine peptidase inhibitor), TLCK (tosyl lysine chloromethyl ketone) and benzamidine (classic trypsin inhibitors), TPCK (tosyl phenylalanine chloromethyl ketone), classic chymotrypsins inhibitor (Bezerra et al., 2005).

Inhibitor type I of $\alpha$-amylase was obtained from the plant Triticum aestivum and was prepared in distilled water at a concentration of $1 \mathrm{mg} / \mathrm{mL}$. Triplicate samples containing mixtures of crude extracts of intestine (trypsin, chymotrypsin and aminopeptidase), liver (amylase), and inhibitor solution at a ratio of 1:1 were incubated for $30 \mathrm{~min}$ at $25^{\circ} \mathrm{C}$. After incubation, enzyme activity assays were carried out as described previously. Negative controls of the enzyme extract and reaction were performed by replacing the substrate buffer and crude extract by $0.15 \mathrm{M} \mathrm{NaCl}$, respectively. A positive control (100\%) was conducted using DMSO without inhibitors.

\subsection{Statistics}

All values were presented as means \pm standard deviations. The inhibition results were analyzed by ANOVA, followed by a post hoc (Tukey) test, when indicated. Differences between groups were accepted as significant at the $95 \%$ confidence level $(p<0.05)$.

\section{Results}

Table 1 shows the activity of digestive peptidases and amylolytic activity present in the digestive tract of juvenile Brazilian flounder. Trypsin (BapNA) and leucineaminopeptidase (Leu-p-Nan) activities were observed in crude extract of intestine. Enzymatic activity using nonspecific substrates was also observed in both alkaline activity (azocasein) as well as the acid activity (hemoglobin) in crude intestine and stomach extract, respectively.

Table 1. Enzymatic activity present in the crude extract of juvenile Brazilian flounder Paralichthys orbignyanus using different substrates.

\begin{tabular}{lcccccc}
\hline & \multicolumn{5}{c}{ Substrates } \\
\cline { 2 - 7 } & *BA $p$ NA 8mM & *Sa $p$ Na $\mathbf{4 m M}$ & $\begin{array}{c}\text { *Leu- } p \text {-Nan } \\
\mathbf{8 m M}\end{array}$ & $\begin{array}{c}\text { *Azocasein } \\
\mathbf{( 1 \% )}\end{array}$ & *Hemoglobin & **Starch $(\mathbf{2 \%})$ \\
\hline Intestine & $0.51 \pm 0.2$ & $2.62 \pm 1.8$ & $0.97 \pm 0.83$ & $3.58 \pm 2.36$ & - & 0 \\
Liver & 0 & 0 & 0 & $0.002 \pm 0.001$ & - & $0.03 \pm 0.00$ \\
Stomach & - & - & - & - & $0.36 \pm 0.25$ & - \\
\hline
\end{tabular}

BApNA - benzoyl arginine $\rho$-nitroanilide, specific for trypsin; Sa $p \mathrm{Na}$ - N-succinyl-Ala-Ala-Pro-Phe-p-nitroanilide, specific for chymotrypsin; Leu- $p$-Nan - aminoacil de $\beta$ - naftilamide, specific for leucine - aminopeptidase; Azocasein, nonspecific for alkaline peptidases; Hemoglobin, nospecific for pepsin; Starch, nonspecific for amylases. - denotes no enzyme mearsurements. $(n=14)$; * $\mathrm{mU} \mathrm{mg}^{-1}$ protein $\pm \mathrm{SD} ; * * \mu \mathrm{g}$ maltose/mg protein. 
Amylolytic activity was detected only in crude extract of the liver, using the nonspecific substrate starch (Table 1). The enzymatic activity of chymotrypsin was also detected in this crude extract, using starch as substrate, while unspecific proteolytic activity was observed using azocasein.

Table 2 indicates the effect of some inhibitors on the enzymatic activity of trypsin, chymotrypsin and leucine aminopeptidase in crude intestine extracts. The inhibitor of serine peptidases (PMSF), benzamidine, and TLCK demonstrated inhibition in all three enzymes (trypsin, chymotrypsin and leucine aminopeptidase). The TPCK specific inhibitor of chymotrypsin did not inhibit trypsin, however did inhibit $60 \%$ of leucine aminopeptidase activity and $79 \%$ of the activity of chymotrypsin. In Table 3 it is possible to observe inhibition effects with the two concentrations of type I inhibitor of $\alpha$-amylase obtained from Triticum aestivum (500 and 1,000 mg/mL $=26 \%$ and $36 \%$ ).

The effects of temperature on the activity of trypsin, chymotrypsin and leucine aminopeptidase present in the crude extract of intestine are shown in Figure 1A, 1D and $1 \mathrm{G}$, respectively. Maximum activity of the three enzymes was

Table 2. Effect of the specific inhibitors on peptidases activity present in the intestine crude extract of juvenile Brazilian flounder Paralichthys orbignyanus.

\begin{tabular}{crcc}
\hline \multirow{2}{*}{ Inhibitors (8mM) } & \multicolumn{3}{c}{ Residual activity (\% \pm SD) } \\
\cline { 2 - 4 } & Ba $p$ Na** & Succ-phe- $p$-NAN** & Leu- $p$-NAN** \\
\hline Control* & $100.0 \pm 0.7 \mathrm{a}$ & $100.0 \pm 3.2 \mathrm{a}$ & $100.0 \pm 5.9 \mathrm{a}$ \\
PMSF & $52.0 \pm 2.3 \mathrm{~b}$ & $42.0 \pm 1.2 \mathrm{~b}$ & $43.0 \pm 1.4 \mathrm{~b}$ \\
TLCK & $33.0 \pm 1.8 \mathrm{c}$ & $45.0 \pm 0.3 \mathrm{c}$ & $44.0 \pm 4.1 \mathrm{~b}$ \\
TPCK & $100.0 \pm 1.2 \mathrm{a}$ & $79.0 \pm 4.5 \mathrm{~d}$ & $60.0 \pm 1.8 \mathrm{c}$ \\
Benzamidine & $41.0 \pm 2.3 \mathrm{~b}$ & $58.0 \pm 0.5 \mathrm{e}$ & $40.0 \pm 1.2 \mathrm{~b}$ \\
\hline
\end{tabular}

*Activity without addition of inhibitors; PMSF: phenylmethylsulphonyl fluoride, serine protease inhibitor; TLCK: tosyl lysine chloromethyl ketone, trypsin inhibitor; TPCK: tosyl phenylalanine chloromethylketone, chymotrypsin inhibitor; Benzamidine: trypsin inhibitor. $(\mathrm{n}=14) ; * * \mathrm{mU} \mathrm{mg}{ }^{-1}$ protein $\pm \mathrm{SD}$; Different superscript letters in column represent statistical differences $(\mathrm{p}<0.05)$.

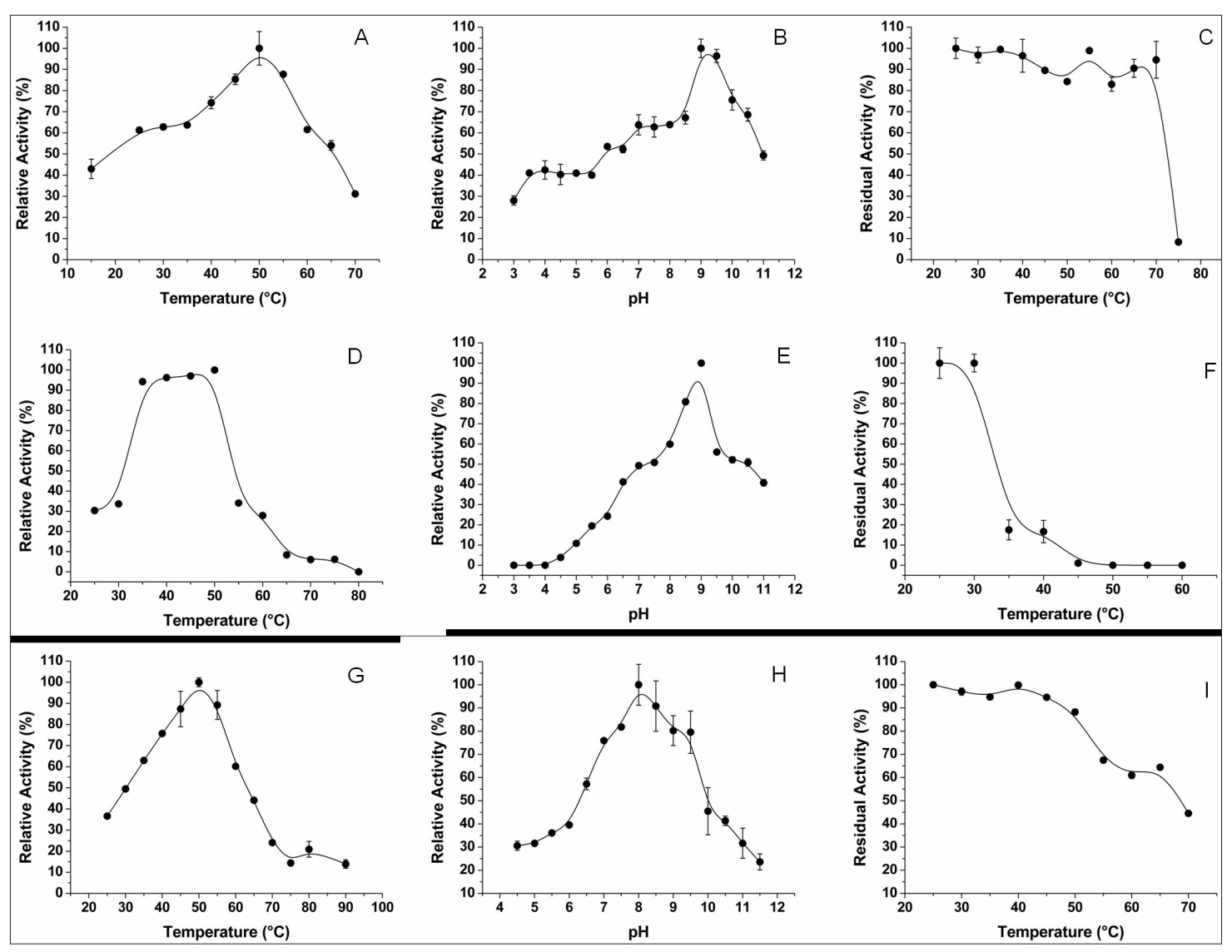

Figure 1. Effects of temperature $(\mathrm{A}, \mathrm{D}, \mathrm{G}), \mathrm{pH}(\mathrm{B}, \mathrm{E}, \mathrm{H})$ and thermal stability $(\mathrm{C}, \mathrm{F}, \mathrm{I})$ in the trypsin, chymotrypsin, leucineaminopeptidase, respectively, activity present in the intestine crude extract of flounder. $(n=14)$; Values are presented as mean $\pm \operatorname{SD}$. 
observed at $50{ }^{\circ} \mathrm{C}$, although more than $80 \%$ of the maximum activity was observed in a range between $40-55^{\circ} \mathrm{C}$ for trypsin (Figure 1A), $35-50{ }^{\circ} \mathrm{C}$ for chymotrypsin (Figure 1D) and $40-55^{\circ} \mathrm{C}$ for leucine aminopeptidase (Figure $1 \mathrm{G}$ ). Enzymatic pepsin activity present in the crude stomach was higher at $50{ }^{\circ} \mathrm{C}$, with over $80 \%$ of its activity being observed in the temperature range of 35 to $50^{\circ} \mathrm{C}$ (Figure $2 \mathrm{~A}$ ). Amylolytic activity present in crude extract of the liver showed a peak in activity at $40{ }^{\circ} \mathrm{C}$, while more than $80 \%$ of the activity was observed at 30 to $55^{\circ} \mathrm{C}$ (Figure 2D).

Results regarding the effects of $\mathrm{pH}$ on enzyme activity revealed increased activity of trypsin present in crude extract of the intestine at $\mathrm{pH}$ values ranging from 9-10 (Figure 1B), while higher enzymatic activity of both chymotrypsin and leucine aminopeptidase occurred in crude extracts of intestine at $\mathrm{pH}$ values ranging from 7.5 to 9.5 (Figure $1 \mathrm{E}$ and $1 \mathrm{H}$, respectively). Pepsin activity present in crude extract of the stomach showed higher activity at $\mathrm{pH}$

Table 3. Effect of a specific inhibitor of amylase activity present in the liver crude extract of juvenile Brazilian flounder Paralichthys orbignyanus.

\begin{tabular}{ccc}
\hline $\begin{array}{c}\text { Inhibidors } \\
(\boldsymbol{\mu g} / \mathbf{m L})\end{array}$ & $\begin{array}{c}\text { Residual activity } \\
(\boldsymbol{\%} \pm \mathbf{S D})\end{array}$ & $\begin{array}{c}\text { Inhibition } \\
(\boldsymbol{\%})\end{array}$ \\
\hline Control* & $100.0 \pm 16.1$ & 0.0 \\
500 & $74.0 \pm 9.6$ & 26.0 \\
1000 & $64.0 \pm 9.1$ & 36.0 \\
\hline
\end{tabular}

Activity without addition of inhibitors, inhibitor of $\alpha$-amylase I obtained from Triticum aestivum. $(\mathrm{n}=14) ;{ }^{*} \mathrm{mU} \mathrm{mg}^{-1}$ protein \pm SD.
2.0 , but $80 \%$ of its activity occurred at $\mathrm{pH}$ values ranging from 1.5-3.5 (Figure 2B). Amylolytic activity present in crude extract of the liver presented a range of enzymatic activity at pH 6.5 to 8.0 (Figure 2E).

Trypsin activity present in crude extract of the intestine was stable in the temperature range of 20 to $70{ }^{\circ} \mathrm{C}$, however all activity ceased at $75^{\circ} \mathrm{C}$ (Figure 1C). Leucine aminopeptidase present in crude extract of the intestine demonstrated thermal stability from 20 to $50{ }^{\circ} \mathrm{C}$ (Figure 1I). The thermal stability of pepsin displayed enzymatic activity above $80 \%$ at temperatures between $25-45{ }^{\circ} \mathrm{C}$ (Figure 2C). Amylolytic activity present in crude extract of the liver indicated residual activities higher than $80 \%$ at temperatures between 25 to $35^{\circ} \mathrm{C}$ (Figure $2 \mathrm{~F}$ ).

\section{Discussion}

Carnivorous fish demonstrate higher pepsin activity than herbivorous fish (Sabapathy and Teo, 1993). The activity of pepsin found in crude extract of the stomach of flounder was higher than that observed for several species of carnivorous fish such as: Glyptosternun maculatum (Xiong et al., 2011) and Thunnus alalunga (Nalinanon et al., 2010). High activity of proteases is important for digesting shellfish organisms such as crustaceans, the principal food item for P. orbignyanus described by Cazorla and Forte (2005).

Amylolytic activity for P. orbignyanus was observed only in the liver. However, in other species, amylolytic activity has been detected in the liver, intestine, bile, stomach and pyloric ceca (Deng et al., 2010; Xiong et al., 2011). According to Krogdahl et al. (2005), the detection
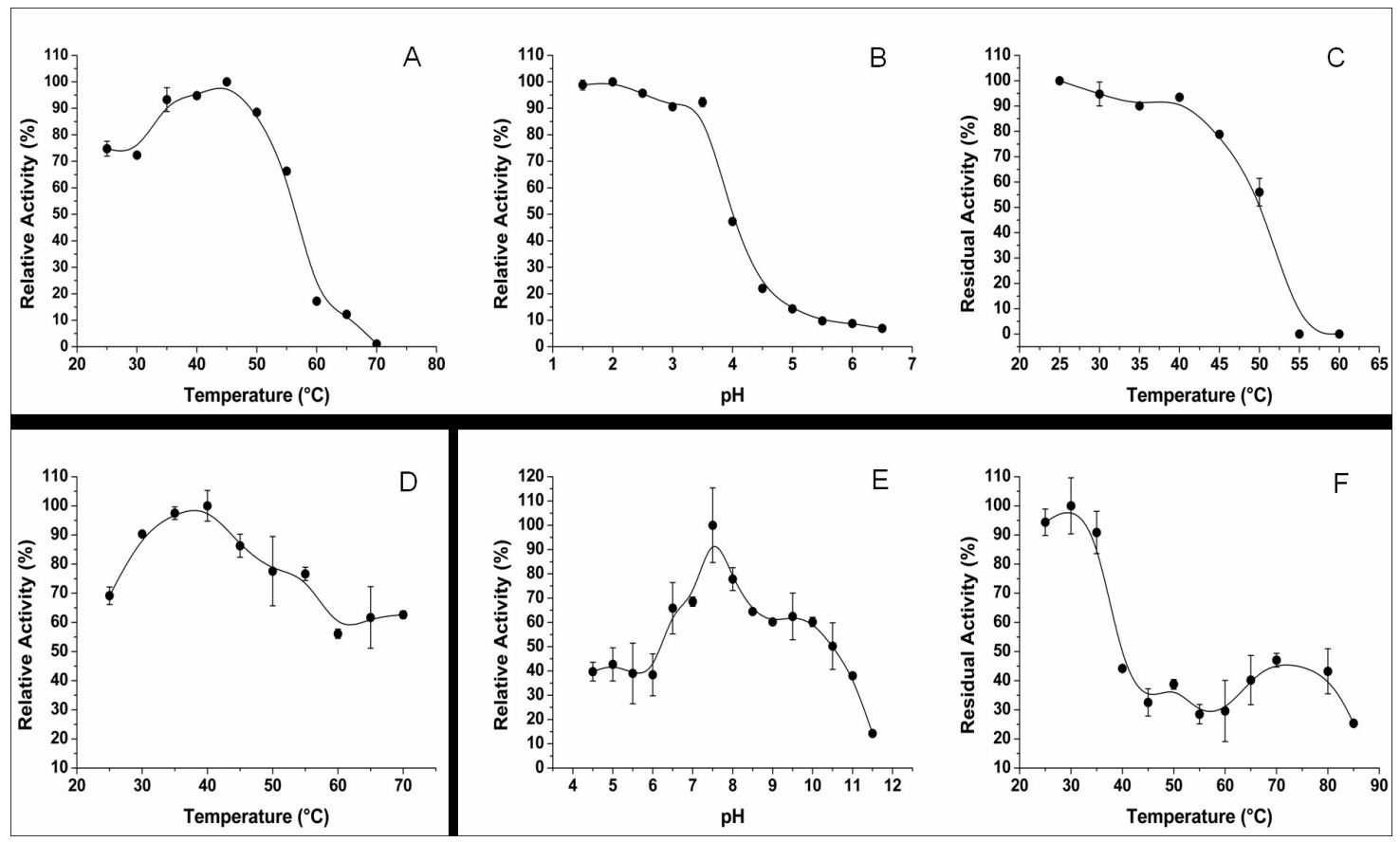

Figure 2. Effects of temperature $(\mathrm{A}, \mathrm{D}), \mathrm{pH}(\mathrm{B}, \mathrm{E})$ and thermal stability $(\mathrm{C}, \mathrm{F})$ using hemoglobin and using starch as substrate activity present in the stomach crude extract of flounder and liver crude extract, respectively. ( $\mathrm{n}=14)$ Values are presented as mean $\pm \mathrm{SD}$. 
of amylase activity in the liver is likely due to the presence of pancreatic tissue, since $\alpha$-amylase in fish is of pancreatic origin only. Amylolytic activity present in the liver may also be of intracellular origin, in which enzymes are related to glycogenolysis (Mehrani and Storey, 1993). Most carnivorous fish demonstrate low or moderate activity of $\alpha$-amylase in the intestine and pancreas (Munilla-Morán and Saborido-Rey, 1996), which is related to the low-carbohydrate diet of these fish in the natural environment (Harpaz and Uni, 1999). This could be the reason why no amylolytic activity was detected in the intestine here, as $P$. obignyanus presents a carnivorous feeding habit (Norbis and Galli, 2004).

\subsection{Effect of $p H$}

$\mathrm{pH}$ exerts an important role on enzyme activity. Márquez et al. (2012) stated that digestion in juvenile/adult fish represents a two-phase process, with an acid phase in the stomach and an alkalinity phase in the intestine. Trypsins of aquatic organisms are active and stable between $\mathrm{pH}$ 7.5-10.0, and are able to hydrolyze various substrates (Vecchi and Coppes, 1996). In this study, trypsin activity presented optimal activity at $\mathrm{pH} 9.5$. For Thunnus orientalist, the highest trypsin activity was observed at $\mathrm{pH} 8.0$, while the same was observed for Paralichthys olivaceus at $\mathrm{pH} 7.5$ (Parra et al., 2007; Kim and Jeong, 2013).

In general, chymotrypsin is more active at $\mathrm{pH} 7.5$ to 8.5 , and more stable at pH 9.0 (Simpson, 2000). Here, chymotrypsin in the Brazilian flounder presented the highest activity at $\mathrm{pH}$ 9.0. The same result was observed for the freshwater Pterygoplichthys disjunctivus (Villalba-Villalba et al., 2013). On the other hand, chymotrypsin from the Japanese sea bass Lateolabrax japonicas demonstrated the highest activity at pH 8.0 (Jiang et al., 2010). Leucine aminopeptidase showed maximun activity at $\mathrm{pH}$ 8.0. Parra et al. (2007) found the same result for Pacific bluefin tuna.

The optimal $\mathrm{pH}$ for amylase at near neutral $\mathrm{pH}$ found in this work has been reported in other studies (MunillaMorán and Saborido-Rey, 1996). However, Fernandéz et al. (2001) observed amylolitic activity for five fish species in a wide $\mathrm{pH}$ range (4-9). Optimum amylase activity varies among fish species, as these enzymes may present more than one isoform (Krogdahl et al., 2005).

Pepsin activity present in crude extract of the stomach showed higher activity at $\mathrm{pH} 2.0$, with $80 \%$ of the activity occurring at $\mathrm{pH}$ ranging from 1.5-3.5. Optimal $\mathrm{pH}$ for pepsin activity has been observed as 2.0 in albacore, wherein its activity was stable in the $\mathrm{pH}$ range of 2.0-5.0 (Nalinanon et al., 2010).

\subsection{Effect of temperature}

Trypsin was active over a wide temperature range, as well as after heat treatment of 30 minutes. Peak trypsin activity occurred at $50{ }^{\circ} \mathrm{C}$, lower than that of other fish species: Astroctosteus tropicus $\left(65^{\circ} \mathrm{C}\right.$; Guerrero-Zarate et al., $2014)$ and tilapia hybrid $\left(60{ }^{\circ} \mathrm{C}\right.$; Wang et al., 2010).

Leucine - aminopeptidase and chymotrypsin present in crude extract of flounder intestine showed similar results to those of trypsin. Sabapathy and Teo (1993) mentioned that leucine - aminopeptidase may compensate for the absence of trypsin activity in bream, digesting oligopeptides into free amino acids for adsorption.

Pepsin activity present in stomach crude extract was active for 30 minutes at temperatures below $45^{\circ} \mathrm{C}$, with a significant loss in activity in temperatures above $50{ }^{\circ} \mathrm{C}$. Similar results were reported by Castillo-Yañes et al. (2004) for Sardinops sagax caerulea. These authors suggest that this feature is important for technological applications, especially in the extraction of collagen.

Peak amylase activity found for $P$. orbignyanus was higher $\left(40^{\circ} \mathrm{C}\right)$ than that found by Xiong et al. (2011) for Glyptosternun maculatum $\left(30^{\circ} \mathrm{C}\right)$. According to Parra et al. (2007), the enzymatic activity of $\alpha$-amylase registered for Thunnus orientalis demonstrates a large temperature range $\left(35\right.$ to $45{ }^{\circ} \mathrm{C}$ ) when compared with other studies (Munilla-Morán and Saborido-Rey, 1996).

\subsection{Effect of inhibitors}

The use of specific inhibitors provides important data regarding the classes of enzymes present in tissue extracts, and may indicate the existence of significant structural differences in enzymes from different species. Peptidase inhibition patterns observed here were not similar to those observed in other species of fish, and neither were the degrees of inhibition. Kim and Jeong (2013) observed complete inhibition for purified trypsin using PMSF, benzamidine and TLCK in olive flounder intestine. Klomklao et al. (2007, 2010) also found complete inhibition in both TLCK and for TPCK for Katsuwonus pelamis and Cololabis saira. Castillo-Yanez et al. (2006) demonstrated 40\% inhibition of trypsin using PMSF and $80 \%$ using benzamidine for pacific sardine. The commercially used inhibitors were developed based on mammalian enzymes; this may explain the different pattern of inhibition observed for Brazilian flounder and other results reported for peptidases from other species of fish and crustacean (Buarque et al., 2009, 2010; GarciaCarreño et al., 1994; Fernández-Gimenez et al., 2002).

Amylolytic activity in crude extract of flounder liver was slightly inhibited by the inhibitor of $\alpha$-amylase obtained from plant Triticum aestivum. This result may be associated with a low sensitivity to this inhibitor for this species. Fernandéz et al. (2001) mentions that the efficacy of $\alpha$-amylase seems to vary between species. The authors further state that the inhibition rate ranged from $0 \%$ to $61 \%$ in five species of Sparidae.

High pepsin activity observed in stomach of $P$. orbignyanus supports the carnivorous - piscivorous feeding habit of this species, enabling digestion of difficult proteins. Moreover, $80 \%$ of pepsin activity was detected between $\mathrm{pH}$ values of 1.5 to 3.5 , which is indicative of the presence of more than one pepsin isoform. Low amylase activity present in liver, and its absence in the intestine portion, supports the fact that this species may display diffulty in dealing with a high dietary inclusion of carbohydrates. These results provide additional information regarding the biology of 
P. orbignyanus and should support further nutritional studies for this species.

\section{Acknowledgements}

Candiotto F.B. is a graduate student of the Aquaculture Program at FURG and is supported by CAPES. Tesser M.B., Sampaio L.A. and Bezerra R.S. received a productivity research fellowship from $\mathrm{CNPq}$. The authors would like to thank Andrew Taylor for revision of English and grammar.

\section{References}

ALAM, M.S., WATANABE, W.O. and DANIELS, H.V., 2009. Effect of different dietary protein and lipid levels on growth performance and body composition of juvenile southern flounder, Paralichthys lethostigma, reared in a recirculating aquaculture system. Journal of the World Aquaculture Society, vol. 40, no. 4, pp. 513-521. http://dx.doi.org/10.1111/j.1749-7345.2009.00274.x.

BERNFELD, P., 1955. Amylases, $\alpha$ and $\beta$. In: S.P. COLOWICK and N.O. KAPLAN, eds. Methods of Enzymology, New York: Academic Press, pp. 149-158.

BEZERRA, R.S., LINS, E.J.F., ALENCAR, R.B., PAIVA, P.M.G., CHAVES, M.E.C., COELHO, L.C.B.B. and CARVALHO JUNIOR, L.B., 2005. Alkaline proteinase from intestine of Nile tilapia (Oreochromis niloticus). Process Biochemistry, vol. 40, no. 5, pp. 1829-1834. http://dx.doi.org/10.1016/j.procbio.2004.06.066.

BIANCHINI, A., SAMPAIO, L.A. and ROBALDO, R.B., 2010. Cultivo de linguado Paralichthys orbignyanus. In: B. BALDISSEROTTO and L.C. GOMES, eds. Espécies nativas para piscicultura no Brasil. 2nd ed. Santa Maria: Editora UFSM, pp. 559-587.

BRADFORD, M.M., 1976. A rapid and sensitive method for the quantitation of microgram quantities of protein utilizing the principle of protein binding. Analytical Biochemistry, vol. 72, no. 1-2, pp. 248-254. PMid:942051. http://dx.doi.org/10.1016/00032697(76)90527-3.

BRASIL. Ministério da Pesca e Aquicultura-MPA, 2010. Boletim estatístico da pesca e aquicultura. Brasília: MPA. 34 p.

BUARQUE, D.S., CASTRO, P.F., SANTOS, F.M.S., AMARAL, I.P.G., OLIVEIRA, S.M., ALVES, K.B., CARVALHO JUNIOR, L.B. and BEZERRA, R.S., 2010. Digestive proteases and peptidases in the hepatopancreas of the Southern brown shrimp (Farfantepenaeus subtilis) in two sub-adult stages. Aquaculture Nutrition, vol. 16, no. 4, pp. 359-369. http://dx.doi.org/10.1111/ j.1365-2095.2009.00673.x.

BUARQUE, D.S., CASTRO, P.F., SANTOS, F.M.S., LEMOS, D., CARVALHO JUNIOR, L.B. and BEZERRA, R.S., 2009. Digestive peptidases in the midgut gland of pink shrimp Farfantepenaeus paulensis (Crustacea, Decapoda, Penaidae). Aquaculture Research, Oxford, vol. 40, no. 7, pp. 861-870. http:// dx.doi.org/10.1111/j.1365-2109.2009.02183.x.

CASTILLO-YAÑES, F.J., PACHECO-AGUILAR, R., GARCÍACARREÑO, F.L., NAVARRETE-DEL-TORO, M.A. and LÓPEZ, M.F., 2004. Characterization of acidic proteolytic enzymes from Monterey sardine (Sardinops sagax caerulea) viscera. Food Chemistry, vol. 85, no. 3, pp. 343-350. http://dx.doi.org/10.1016/j. foodchem.2003.07.008.
CASTILLO-YAÑEZ, F.J., PACHECO-AGUILAR, R., GARCÍACARREÑO, F.L., NAVARRETE-DEL TORO, M.A. and LÓPEZ, M.A., 2006. Purification and biochemical characterization of chymotrypsin from the viscera of Monterey sardine (Sardinops sagax caeruleus). Food Chemistry, vol. 99, no. 2, pp. 252-259. http://dx.doi.org/10.1016/j.foodchem.2005.06.052.

CAZORLA, A.L. and FORTE, S., 2005. Food and feeding habits of flounder Paralichthys orbignyanus (Jenyns, 1842) in Bahía Blanca Estuary, Argentina. Hydrobiology, vol. 549, no. 1, pp. 251-257. http://dx.doi.org/10.1007/s10750-005-5446-x.

DENG, J., MAI, K., AI, Q., ZHANG, W., TAN, B., XU, W. and LIUFU, Z., 2010. Alternative protein sources in diets for japoneses flounder Paralichthys olivaceus (Temminck and Schlegel): II. Effects on nutrient digestibility and digestive enzyme activity. Aquaculture Research, vol. 41, no. 6, pp. 861-870. http://dx.doi. org/10.1111/j.1365-2109.2009.02363.x.

FERNÁNDEZ GIMENEZ, A.V., GARCÍA-CARREÑO, F.L., NAVARRETE DEL TORO, M.A. and FENUCCI, J.L., 2002. Digestive proteinases of Artemesia longinaris (Decapoda, Penaeidae) and relationship with molting. Comparative Biochemistry and Physiology, vol. 132, no. 3, pp. 593-598. PMid:12091105. http:// dx.doi.org/10.1016/S1096-4959(02)00080-5.

FERNANDÉZ, I., MOYANO, F.J., DIAZ, M. and MARTINEZ, T., 2001. Characterization of alpha-amylase activity in five species of Mediterranean sparid fishes (Sparidae, Teleostei). Journal of Experimental Marine Biology and Ecology, vol. 262, no. 1, pp. 1-12. http://dx.doi.org/10.1016/S0022-0981(01)00228-3.

GARCIA-CARREÑO, F.L., HERNÁNDEZ-CORTÉZ, M.P. and HAARD, N.F., 1994. Enzymes with peptidase and proteinase activity from the digestive systems of a freshwater and a marine decapode. Journal of Agricultural and Food Chemistry, vol. 42, no. 7, pp. 1456-1461. http://dx.doi.org/10.1021/jf00043a013.

GATLIN III, D.M., 2010. Principles of fish nutrition. Stoneville: Southern Regional Aquaculture Center, vol. 5003, 8 p.

GUERRERO-ZÁRATE, R., ALVAREZ-GONZÁLEZ, C.A., OLVERA-NOVOA, M.A., PERALES-GARCÍA, N. FRÍAZQUINTANA, C.A. MARTÍNEZ-GARCÍA, R. and CONTRERASSÁNCHEZ, W.M., 2014. Partial characterization of digestive proteases in tropical gar Astroctosteus tropicus juveniles. Fish Physiology and Biochemistry, vol. 40, no. 4, pp. 1021-1029. PMid:24379163. http://dx.doi.org/10.1007/s10695-013-9902-7.

HARPAZ, S. and UNI, Z., 1999. Activity of intestinal mucosal brush border membrane enzymes in relation to the feeding habits of three aquaculture fish species. Comparative Biochemistry and Physiology, vol. 124A, no. 2, pp. 155-160. http://dx.doi. org/10.1016/S1095-6433(99)00106-3.

JIANG, Y.K., SUN, L.C., CAI, Q.F., LIU, G.M., YOSHIDA, A., OSATOMI, K. and CAO, M.J., 2010. Biochemical characterization of chymotrypsins from the hepatopancreas of japanese sea bass (lateolabrax japonicus). Journal of Agricultural and Food Chemistry, vol. 58, no. 13, pp. 8069-8076. PMid:20568769. http://dx.doi.org/10.1021/jf101970h.

KHALED, H.B., GHORBEL-BELAAJ, O., HMIDET, N., JELLOULI, K., ALI, N.E.H., GHORBEL, S. and NASRI, M., 2011. A novel aspartic protease from the viscera of Sardinelle (Sardinella aurita): Purification and characterization. Food Chemistry, vol. 128, no. 4, pp. 847-853. http://dx.doi.org/10.1016/j. foodchem.2011.03.104.

KIM, M. and JEONG, Y., 2013. Purification and characterization of a trypsin-like protease from flatfish (Paralichthys olivaceus) 
intestine. Journal of Food Biochemistry, vol. 37, no. 6, pp. 732741. http://dx.doi.org/10.1111/j.1745-4514.2012.00672.x.

KLOMKLAO, S., BENJAKUL, S., VISESSANGUAN, W., KISHIMURA, H. and SIMPSON, B.K., 2007. Purification and characterization of trypsins from the spleen of skipjack tuna (Katsuwonus pelanis). Food Chemistry, vol. 100, no. 4, pp. 1580-1589. http://dx.doi.org/10.1016/j.foodchem.2006.01.001.

KLOMKLAO, S., KISHIMURA, H., BENJAKUL, S., SIMPSON, B.K. and VISESSANGUAN, W., 2010. Cationic trypsin: A predominant proteinase in Pacific saury (Cololabis saira) pyloric ceca. Journal of Food Biochemistry, vol. 34, no. 5, pp. 1105-1123. http://dx.doi.org/10.1111/j.1745-4514.2010.00352.x.

KROGDAHL, A., HEMRE, G.I. and MOMMSEN, T.P., 2005. Carbohydrates in fish nutrition: digestion and absorption in postlarval stages. Aquaculture Nutrition, vol. 11, no. 2, pp. 103-122. http://dx.doi.org/10.1111/j.1365-2095.2004.00327.x.

KUZ'MINA, V.V., SKVORTSOVA, E.G., ZOLOTAREVA, G.V. and SHEPTITSKIY, V.A., 2011. Influence of $\mathrm{pH}$ upon the activity of glycosidases and proteinases of intestinal mucosa, chyme and microbiota in fish. Fish Physiology and Biochemistry, vol. 37, no. 3, pp. 345-353. PMid:21082240. http://dx.doi.org/10.1007/ s10695-010-9426-3.

LEMIEUX, H., BLIER, P. and DUTIL, J.-D., 1999. Do digestive enzymes set a physiological limit on growth rate and food conversion efficiency in the Atlantic cod (Gadus morhua)? Fish Physiology and Biochemistry, vol. 20, no. 4, pp. 293-303. http:// dx.doi.org/10.1023/A:1007791019523.

LOPEZ-LOPEZ, S., NOLASCO, H., VILLARREALCOLMENARES, H. and CIVERA-CERECEDO, R., 2005. Digestive enzyme response to supplemental ingredients in practical diets for juvenile freshwater crayfish Cheraz quadricarinatus. Aquaculture Nutrition, vol. 11, no. 2, pp. 79-85. http://dx.doi. org/10.1111/j.1365-2095.2004.00305.x.

MÁRQUEZ, L., ROBLES, R., MORALES, G.A. and MOYANO, F.J., 2012. Gut $\mathrm{pH}$ as limiting factor for digestive proteolysis in cultured juveniles of the gilthead sea brem (Sparus aurata). Fish Physiology and Biochemistry, vol. 38, no. 3, pp. 859-869. PMid:22086356. http://dx.doi.org/10.1007/s10695-011-9573-1.

MEHRANI, H. and STOREY, K.B., 1993. Characterization of a-glucosidases from rainbow trout liver. Archives of Biochemistry and Biophysics, vol. 306, no. 1, pp. 188-194. PMid:8215402. http://dx.doi.org/10.1006/abbi.1993.1499.

MUNILLA-MORÁN, R. and SABORIDO-REY, F., 1996. Digestive enzymes in marine species. I. Proteinase activities in gut from redfish (Sebastes mentella), seabream (Sparus aurata) and turbot (Scophthalmus maximus). Comparative Biochemistry and Physiology, vol. 113B, no. 2, pp. 395-402. http://dx.doi. org/10.1016/0305-0491(95)02057-8.

NALINANON, S., BENJAKUL, S. and KISHIMURA, H., 2010. Biochemical properties of pepsinogen and pepsin from the stomach of albacore tuna (Thunnus alalunga). Food Chemistry, vol. 121, no. 1, pp. 49-55. http://dx.doi.org/10.1016/j.foodchem.2009.11.089.
NORBIS, W. and GALLI, O., 2004. Feeding habits of the flounder Paralichthys orbignyanus (Valenciennes, 1842) in a shallow coastal lagoon of the southern Atlantic Ocean: Rocha, Uruguay. Ciencias Marinas, vol. 30, no. 4, pp. 619-626. http:// dx.doi.org/10.7773/cm.v30i4.338.

PARRA, A.M., ROSAS, A., LAZO, J.P. and VIANA, M.T., 2007. Partial characterization of the digestive enzymes of Pacific bluefin tuna Thunnus orientalis under culture conditions. Fish Physiology and Biochemistry, vol. 33, no. 3, pp. 223-231. http:// dx.doi.org/10.1007/s10695-007-9134-9.

SABAPATHY, U. and TEO, L.H., 1993. A quantitative study of some digestive enzymes in the rabbitfish, Siganus canaliculatus and the sea bass, Lates calcarifer. Journal of Fish Biology, vol. 42, no. 4, pp. 595-602. http://dx.doi.org/10.1111/j.1095-8649.1993. tb00362.x

SAMPAIO, L.A., FREITAS, L.S., OKAMOTO, M., LOUZADA, L.R., RODRIGUES, R.V. and ROBALDO, R.B., 2007. Effects of salinity on Brazilian flounder Paralichthys orbignyanus from fertilization to juvenile settlement. Aquaculture, vol. 262, no. 2-4, pp. 340-346. http://dx.doi.org/10.1016/j.aquaculture.2006.09.046.

SAMPAIO, L.A., ROBALDO, R.R. and BIANCHINI, A., 2008. Hormone-induced ovulation, natural spawning and larviculture of Brazilian flounder Paralichthys orbignyanus (Valenciennes, 1839). Aquaculture Research, vol. 39, no. 7, pp. 712-717. http:// dx.doi.org/10.1111/j.1365-2109.2008.01923.x.

SIMPSON, B.K., 2000. Digestive proteases from marine animals. In: M. DEKKER, ed. Seafood Enzymes. New York: Marcel Dekker, pp 191-213.

VECCHI, S. and COPPES, Z., 1996. Marine fish digestive proteases - relevance to food industry and the southwest Atlantic region: a review. Journal of Food Biochemistry, vol. 20, no. 1, pp. 193-214. http://dx.doi.org/10.1111/j.1745-4514.1996.tb00551.x.

VILLALBA-VILLALBA, A.G., RAMÍREZ-SUÁREZ, J.C., PACHECO-AGUILAR, R., VALENZUELA-SOTO, E.M., LUGO-SÁNCHEZ, M.E. and FIGUEROA-SOTO, C.G., 2013. Purification and characterization of chymotrypsin from viscera of vermiculated sailfin catfish, Pterygoplichthys disjunctivus, Weber, 1991. Fish Physiology and Biochemistry, vol. 39, no. 2, pp. 121-130. PMid:22752357. http://dx.doi.org/10.1007/ s10695-012-9684-3

WANG, Q., GAO, Z.X., ZHANG, N., SHI, Y., XIE, X.L. and CHEN, Q.X., 2010. Purification and characterization of trypsin from the intestine of hybrid tilapia (Oreochromis niloticus x O.aureus). Journal of Agricultural and Food Chemistry, vol. 58, no. 1, pp. 655-659. PMid:19899756. http://dx.doi.org/10.1021/jf903052s.

XIONG, D.M., XIE, C.X., ZHANG, H.J. and LIU, H.P., 2011. Digestive enzymes along digestive tract of a carnivorous fish Glyptosternum maculatum (Sisoridae, Siluriformes). Journal of Animal Physiology and Animal Nutrition, vol. 95, no. 1, pp. 56-64. PMid:20487102. http://dx.doi.org/10.1111/j.14390396.2009.00984.x. 